\title{
Pattern of Microbial Infections during the First 72 Hours of Neonate Life at Khafji General Hospital Neonatal Intensive Care Unit
}

\author{
Lina Eltaib ${ }^{1 *}$ and Hadir A. Alshammari ${ }^{2}$ \\ 'Department of Pharmaceutics, Faculty of Pharmacy, Northern Border University, Arar, Saudi Arabia; \\ linasalaheldin@gmail.com \\ ${ }^{2}$ AlKhafji General Hospital, Khafji - 39256, Saudi Arabia
}

\begin{abstract}
Neonatal infection is an important cause of morbidity and mortality of neonates. The objective of this study is to evaluate the pattern of microbial infections during the first 72 hours of neonate life at AlKhafji General Hospital Neonatal Intensive Care Unit. This is a hospital-based retrospective study design in AlKhafji General Hospital (KGH) in Khafji City, Saudi Arabia. The data was collected from sensitivity reports and results of isolated cultures of random sample of 74 infected neonates admitted to NICU. Data was analyzed by SPSS program by descriptive statistics. Among the 74 significant culture positive cases, there were $54 \%$ male and $46 \%$ female neonates. The most common microorganism isolated from neonates in NICU was Pseudomonas aeruginosa (13.5\%) followed by E. coli and Enterobacter (12.1\%) and (9.5\%) respectively. 18.9\% of the isolated bacteria were sensitive to vancomycin including Staphylococcus aureus, Staphylococcus hominis, Enterobacter, MRSA, Enterococi, C. diff and Listeria monocytogenes. 12.2\% of the isolated bacteria were sensitive to ampilcillin including Staphylococcus aureus, Acinetobacter, Enterobacter, Strep. pyogenses, Enterococi and Anaerobes. $10.8 \%$ of the isolates were sensitive to imipenem including Phenomena paucimobilis, Staphylococcus hominis, E. coli, Enterobacter, Staphylococcus sciuri and Pseudomonas aeruginosa. Gram negative bacteria specifically Pseudomonas aeruginosa and E. coli are the most common causes of infection of neonates in NICU. Pathogens causing neonatal infections exhibit varying antibiotic sensitivity pattern. However, the most sensitivity recorded was for vancomycin. Additionally, the emerging multi drug resistant microorganism such as Acinetobacter in NICUs could be a health risk in future.
\end{abstract}

Keywords: Intensive Care Unit, Microbial Infections, Neonatal, Treatment

\section{List of Abbreviations}

C. diff: Clostridium difficile.

CDC: Center for Disease Control and prevention.

CoNS: Caoagulase-negative staphylococci.

CVA catheter: Central Venous catheter.

E. coli: Escherichia coli.

HSV: Herpes Simplex Virus.

GBS: Group B Streptococcus.

GDS: Group D Streptococcus.

MRSA: Methicillin-resistant Staphylococcus aureus.
MSSA: Methicillin- susceptiple Staphylococcus aureus.

NICU: Neonatal Intensive Care Unit.

VLBW: Very Low Birth Weight.

WHO: World Health Organization.

\section{Introduction}

Neonatal infection is an important cause of morbidity and mortality of neonates. Additionally, it is a major cause for prolonged admission among infants, particularly preterm

${ }^{*}$ Author for correspondence 
infants and newborns with Very Low Birth Weight $(\mathrm{VLBW})^{1}$.

Neonates are highly prone to infections and if not diagnosed and treated quickly, may lead to fatality ${ }^{2}$. Suspected infections including meningitis, pneumonia and sepsis account for an estimated 1.4 million neonatal deaths worldwide every year ${ }^{3}$. After the first week of life; infections are the main cause of neonatal mortality in many countries ${ }^{4}$. These infections can be acquired by the infant in different ways e.g. complications of treatment or other prenatal conditions and can be acquired in hospital (hospital-acquired or nosocomial infection) or at home (community acquired infection) $)^{4}$.

The survival rate of low birth weight and very low birth weight neonates in a Newborn Intensive Care Unit (NICU) has increased in recent years due to technological advancement, but the prolonged duration of admission and the number of invasive procedures may increase nosocomial infections ${ }^{5}$. Neonates' infections have a wide range of manifestations including osteomyelitis, arthritis, pneumonia, meningitis, septicemia and urinary tract infections ${ }^{6}$.

\section{Rationale of the Study}

To decrease mortality rate, it is necessary to treat neonatal infections rapidly by empirical use of suitable antimicrobial medications. The selection of empirical antimicrobial has always been based on the given data on type of microorganism and epidemiology of bacterial sensitivity patterns ${ }^{7}$.

The bacterial resistances to antibiotics become a major problem in most hospitals or health care facilities all over the world, particularly in developing countries due to inappropriate and random use of antibiotics. Center for Disease Control and prevention (CDC) reported that many types of bacteria become resistant to two or more classes of antibiotics in both large and small hospitals ${ }^{8}$.

Although many cases of infections occur in the first hours of the newborn life, however, no previous studies have been carried to evaluate the pattern of microorganism's infection of newborn in the first few hours of their life in Khafii- Saudi Arabia. The objective of the study is to evaluate the pattern of microbial infections during the first 72 hours of neonate life in Neonatal Intensive Care Unit.
Sepsis diagnosis depends mainly on the newborn's symptoms and the laboratory results. Several tests need to be conducted to try to determine the specific bacterium, virus or fungus that is causing the infection'.

According to the WHO "Infant mortality rate is about five million annually, $98 \%$ of which occurs in poor countries". Based on these data, early-onset sepsis is associated with acquisition of microorganisms from the mother ${ }^{10}$.

Hospital-acquired (nosocomial) infection is critical and often difficult to control in the Neonatal Intensive Care Unit $(\mathrm{NICU})^{11}$. Various NICUs acquire different types of pathogens ${ }^{12}$ which is acquired during the first two to three days after hospitalization ${ }^{13}$. This type of infections increases the length of hospitalization and healthcare costs $^{14}$.

In 2005, the WHO declares "more than 1.4 million people per year suffer from hospital acquired infections. Currently the incidence rate of hospital-acquired infections is approximately $25 \%$ in developing countries ${ }^{15}$.

Early onset sepsis often manifests with pneumonia and/or septicaemia. There is a high risk of mortality. Sepsis at this early age is predominantly due to organisms acquired from the birth canal. Occasionally intrapartum haematogenous spread occurs such as listeria. Over $80 \%$ of cases are due to Group B Streptococcus (GBS) and Gram negative bacteria ${ }^{16}$. Neonatal sepsis arises when pathogenic microorganisms gain entry into the bloodstream causing devastating systemic infection. Risk factors of sepsis include: Underweight, long hospitalization, antibiotics consumption, storage of medical supply, along with using procedures such as: Parenteral nutrition with lipid emulsions, endotracheal tube, ventricular shunt, intravascular catheter ${ }^{17,18}$.

Sepsis a cause of neonatal mortality encompasses various neonatal infections: septicemia, meningitis, pneumonia, arthritis, osteomyelitis and urinary tract infections. Superficial infections like conjunctivitis and oral thrush are not usually included under neonatal sepsis $^{19,20}$.

Among the pathogens causing hospital-acquired infections, $C$. difficile (12.1\%) is the leading cause followed by Staphylococcus aureus (10.7\%), Klebsiella (9.9\%) and Escherichia coli $(9.3 \%)^{21}$. Health care providerassociated infection via contaminated worker and fomite transmission has been well documented ${ }^{22,23}$.

The clinical manifestations of neonatal sepsis vary considerably and are nonspecific, which makes the 
diagnosis of early difficult, symptoms may include body temperature instability, unexplained jaundice, Apnea, tachypnea, dyspnea, flaring, retractions, grunting, or cyanosis $^{24,25}$.

Gram-negative bacteremia carries higher risks of severe sepsis, septic shock and death. Sundaram et al. ${ }^{26}$ Gram-negative Bacilli (GNB) are well-described causes of Healthcare-associated Infections (HAIs) among infants hospitalized in Neonatal Intensive Care Units (NICUs) ${ }^{27}$.

\section{Materials and Methods}

Hospital based retrospective study design in Khafi General Hospital (KGH) in Khafji City Saudi Arabia.

Add IRB approval number.

The data was collected by analyzing sensitivity reports and results of isolated cultures of infected neonates admitted to NICU using data collection sheet (attached in the appendix) from October 2019 to March 2020. Random sample of 74 infected neonates admitted to NICU.

\subsection{Inclusion Criteria}

- Infected neonates in ICU in their first 72 hours of their life.

- Admitted to NICU in the period from June 2017 till June 2018.

\subsection{Exclusion Criteria}

- Neonates infected after the first 72 hours of their life.

\subsection{Statistical Test}

After data collection, all data coded and entered to excel spread sheet then transferred to SPSS program for statistical analysis. Descriptive statistics used for data analysis with calculation of frequency and percentage for categorical data and calculation of minimum, maximum and mean (SD) for continuous data and representing the results with figures.

\section{Results}

Among the 74 significant culture positive cases, there were 40 (54\%) male and 34 (46\%) female neonates. Table 1 gestational age of the included neonates ranged from 30 to 39 weeks with mean 35 weeks, birth weight of the neonates included ranged from 1874 to $3890 \mathrm{gm}$ with mean 2870 gm (Table 2).

Blood cultures accounted for $(32.4 \%)$ of the total isolates, urine cultures accounted for $40.5 \%$ of the isolates and stool culture accounted for $10.8 \%$ of the isolates. Figure 1 shows the sources of culture among study subjects.

The most common microorganism isolated from neonates in NICU was Pseudomonas aeruginosa (13.5\%) followed by E. coli and Enterobacter (12.1\%) and (9.5\%) respectively. Other microorganisms isolated were Methecillin Resistant Staphylococcus aureus (MRSA) (6.8\%), Staph. aureus (5.4\%) and Neisseria mengitidis (5.4\%). Figure 4 show the details about microorganisms isolated from NICU.

The gram negative bacteria isolated from 37 (50\%) of neonates; mainly Pseudomonas aeruginosa (13.5\%) and $E$. coli (12.1\%). The gram positive bacteria isolated from 30 (40.5\%); mainly Staphylococcus aureus (5.4\%). Figure 3 shows distribution of isolated bacteria according to gram stains affinity.

Table 3 shows the isolated microorganisms according to source of culture.

Pseudomonas aeurginosa isolated from blood (4.1\%), urine $(2.7 \%)$ and throat (2.7\%). MRSA isolated from urine (5.4\%), Strep. pyogenes isolated from urine (1.45) and blood (1.4\%).

$18.9 \%$ of the isolated bacteria were sensitive to vancomycin including Staph aureus, Staphylococcus hominis, Enterobacter, MRSA, Enterococi, C. diff and Listeria monocytogenes. $12.2 \%$ of the isolated bacteria were sensitive to ampilcillin including Staph. aureus, Acinetobacter, Enterobacter, Strep. pyogenses, Enterococi and Anaerobes. $10.8 \%$ of the isolates were sensitive to imipenem including Phingomonas paucimobilis, Staphylococcus hominis, E. coli, Enterobacter, Staphylococcus sciuri and Pseudomonase. Table 4 shows sensitivity pattern of isolated microorganisms from positive culture from NICU.

Death rate among infected neonates was $12.2 \%$ (Table 5). Among them there were $77.8 \%$ females, the most causative agent of infection isolated was Neisseria mengitidis (22.2\%) and Pseudomonas aeurginosa (22.2\%). Their gestational age ranged from 30 to 35 weeks with mean 32-34 weeks and their birth weight ranged from 1894 to 2890 gm with mean 2491 gm Table 6. 
Table 1. Distribution of study subjects according to gender

\begin{tabular}{|c|c|c|c|}
\hline Variable & Categories & Frequency & Percentage \\
\hline \multirow{2}{*}{ Sex } & Male & 40 & $54 \%$ \\
\cline { 2 - 4 } & Female & 34 & $46 \%$ \\
\hline
\end{tabular}

Table 2. Distribution of study subjects according to birth weight and gestational age

\begin{tabular}{|c|c|c|c|c|}
\hline Variable & Maximum & Minimum & Mean & $\begin{array}{c}\text { Standard } \\
\text { deviation }\end{array}$ \\
\hline $\begin{array}{c}\text { Birth weight } \\
\text { (gm) }\end{array}$ & 3890 & 1874 & 2870 & 514.7 \\
\hline $\begin{array}{c}\text { Gestational } \\
\text { age (weeks) }\end{array}$ & 39 & 30 & 35 & 2.4 \\
\hline
\end{tabular}

\section{Discussion}

The immune system of the new born is usually unable to provide a robust defense against virulent pathogen faced in the postnatal environment. So, neonates are at high risk of developing invasive infection if exposed to pathogenic microorganisms especially premature neonates due to lack of protective maternal antibodies, underdeveloped innate immunity ${ }^{28}$, Advanced medical technology, appropriate infection prevention, and proper patient counseling on the use of antibiotics determine the prevalence of newborns diseases, particularly those who depend on therapeutic interventions for survival ${ }^{29,30}$.

The frequency of infection in NICUs varies from $8 \%$ to $10 \%$ in Europe and from $6 \%$ to $25 \%$ in the United States $^{31}$. The present study conducted to evaluate the

Table 3. Isolated microorganism according to source of culture

\begin{tabular}{|c|c|c|c|c|c|c|c|c|}
\hline Microorganism & $\begin{array}{c}\text { Wound } \\
\text { swab }\end{array}$ & throat & urine & blood & $\begin{array}{c}\text { CVA } \\
\text { catheter }\end{array}$ & $\begin{array}{c}\text { Eye } \\
\text { discharge }\end{array}$ & $\begin{array}{c}\text { Nasal } \\
\text { discharge }\end{array}$ & Stool \\
\hline Acinetobacter & 0 & 0 & 0 & 0 & $1(1.4 \%)$ & 0 & 0 & 0 \\
\hline Actinomyces & 0 & 0 & $1(1.4 \%)$ & 0 & 0 & 0 & 0 & 0 \\
\hline Atypical & 0 & 0 & $1(1.4 \%)$ & 0 & 0 & 0 & 0 & 0 \\
\hline C. diff & 0 & 0 & $1(1.4 \%)$ & 0 & 0 & 0 & $1(1.4 \%)$ & $1(1.4 \%)$ \\
\hline Candida. albicans & 0 & 0 & $4(5.4 \%)$ & 0 & 0 & 0 & 0 & 0 \\
\hline $\begin{array}{c}\text { Candida. non. } \\
\text { albicans }\end{array}$ & 0 & 0 & $1(1.4 \%)$ & 0 & 0 & 0 & 0 & 0 \\
\hline $\begin{array}{c}\text { Chlamydia } \\
\text { trachomatis }\end{array}$ & 0 & 0 & $2(2.7 \%)$ & 0 & 0 & $1(1.4 \%)$ & 0 & 0 \\
\hline E. coli & 0 & 0 & $1(1.4 \%)$ & $1(1.4 \%)$ & 0 & 0 & 0 & $4(5.4 \%)$ \\
\hline Enterobacter & 0 & 0 & $3(4.1 \%)$ & $4(5.4 \%)$ & 0 & 0 & 0 & 0 \\
\hline Enterococi & 0 & 0 & 0 & $3(4.1 \%)$ & 0 & 0 & 0 & 0 \\
\hline HSV & 0 & $1(1.4 \%)$ & 0 & 0 & 0 & 0 & 0 & 0 \\
\hline $\begin{array}{c}\text { Listeria } \\
\text { monocytogenes }\end{array}$ & 0 & 0 & 0 & 0 & 0 & 0 & 0 & 1 (1.4\%) \\
\hline MRSA & 0 & 0 & $4(5.4 \%)$ & $1(1.4 \%)$ & 0 & 0 & 0 & 0 \\
\hline MSSA & 0 & 0 & $1(1.4 \%)$ & $1(1.4 \%)$ & 0 & 0 & 0 & $1(1.4 \%)$ \\
\hline $3(4.1 \%)$ & 0 & $1(1.4 \%)$ & 0 & 0 & 0 & $1(1.4 \%)$ & 0 & N. mengitidis \\
\hline $1(1.4 \%)$ & 0 & 0 & 0 & 0 & 0 & 0 & 0 & $\begin{array}{c}\text { Sphingomonas } \\
\text { paucimobilis }\end{array}$ \\
\hline 3 (4.1\%) & 0 & 0 & $1(1.4 \%)$ & $1(1.4 \%)$ & $2(2.7 \%)$ & $2(2.7 \%)$ & 0 & Pseudomonas \\
\hline 0 & 0 & 0 & 0 & 0 & 0 & $1(1.4 \%)$ & 0 & Staph. epidermis \\
\hline 2 (2.7\%) & 0 & 0 & $1(1.4 \%)$ & 0 & 0 & 0 & $1(1.4 \%)$ & Staph. aureus \\
\hline 1 (1.4\%) & 0 & 0 & 0 & 0 & 0 & 0 & 0 & $\begin{array}{c}\text { Staphylococcus } \\
\text { hominis }\end{array}$ \\
\hline
\end{tabular}




\begin{tabular}{|c|c|c|c|c|c|c|c|c|}
\hline 0 & 0 & 0 & 0 & 0 & 0 & $3(4.1 \%)$ & 0 & Staphylococcus sciuri \\
\hline $1(1.4 \%)$ & 0 & 0 & 0 & 0 & 0 & 0 & 0 & $\begin{array}{c}\text { Staphypylococcus } \\
\text { capitis }\end{array}$ \\
\hline & 0 & 0 & $1(1.4 \%)$ & 0 & 0 & 0 & 0 & Stenotrophomonas sp. \\
\hline $1(1.4 \%)$ & 0 & 0 & 0 & 0 & 0 & $1(1.4 \%)$ & 0 & Strep. pyogenes \\
\hline 0 & 0 & 0 & $1(1.4 \%)$ & 0 & 0 & $1(1.4 \%)$ & 0 & Strep. pneumoniae \\
\hline
\end{tabular}

Table 4. Sensitivity pattern of isolated microorganisms from positive culture from NICU

\begin{tabular}{|c|c|c|}
\hline Antibiotic & $\begin{array}{c}\text { Frequency } \\
\text { (percentage) }\end{array}$ & Sensitive microorganisms \\
\hline Vancomycin & $14(18.9 \%)$ & $\begin{array}{c}\text { Staph. aureus, Staphylococcus hominis, Enterobacter, MRSA, Enterococi, C. } \\
\text { diff and Listeria monocytogenes }\end{array}$ \\
\hline Gentamycin & $5(6.8 \%)$ & Sphingomonas paucimobilis, Staph aureus and Staphylococcus sciuri \\
\hline Amikacin & $2(2.7 \%)$ & Streptococcus agalactiae \\
\hline Imipenem & $8(10.8 \%)$ & $\begin{array}{c}\text { Sphingomonas paucimobilis, Staphylococcus hominis, E. coli, Enterobacter, } \\
\text { Staphylococcus sciuri and Pseudomonase }\end{array}$ \\
\hline Ceftriaxone & $3(4.1 \%)$ & Acinetobacter, Strep. pneumoniae and Chlamydia trachomatis \\
\hline Ampicillin & $9(12.2 \%)$ & $\begin{array}{c}\text { Staph. aureus, Acinetobacter, Enterobacter, Strep. pyogenses, Enterococi } \\
\text { and anaerobes }\end{array}$ \\
\hline Piperacillin & $5(6.8 \%)$ & E. coli and Pseudomonas \\
\hline Amoxicillin/clavulanic acid & $1(1.4 \%)$ & E. coli \\
\hline Fluconazole & $3(4.1 \%)$ & Candida. Albicans and Candida non. albicans \\
\hline Pencillin & $4(5.4 \%)$ & Strep. pyogenes and N. meningitidis \\
\hline Cefuroxime & $3(4.1 \%)$ & Streptococcus agalactiae \\
\hline Piperacillin & $2(2.7 \%)$ & Enterobacter, E. coli and Pseudomonas \\
\hline Cefotaxime & $4(5.4 \%)$ & Staph. aureus and E. coli \\
\hline Ceftazidime & $3(4.1 \%)$ & Pseudomonas \\
\hline Levofloxacin & $2(2.7 \%)$ & Stenotrophomonas s.p and Strep. pneumonia \\
\hline Cefepime & $2(2.7 \%)$ & Pseudomonase and E. coli \\
\hline Cefazoline & $3(4.1 \%)$ & MRSA and MSSA \\
\hline Ceftaroline & $3(4.1 \%)$ & $M R S A$ \\
\hline Erythromycin & $2(2.7 \%)$ & Chlamydia trachomatis \\
\hline Linezolid & $1(1.4 \%)$ & Staph. aureus \\
\hline Clindamycin & $2(2.7 \%)$ & Staph. epidermis and Strep. pyogenses \\
\hline Azithromycin & $1(1.4 \%)$ & Atypical \\
\hline Acyclovir & $1(1.4 \%)$ & $H S V$ \\
\hline Metronidazole & $1(1.4 \%)$ & C. diff \\
\hline Doxycycline & $1(1.4 \%)$ & Chalamydia \\
\hline Pencillin G & $1(1.4 \%)$ & N. mengitidis \\
\hline Pencillin VK & $3(4.1 \%)$ & Actinomyces and N. mengitidis \\
\hline Dicloxacillin & $1(1.4 \%)$ & Staph. aureus \\
\hline
\end{tabular}


Table 5. Death rate in the study sample

\begin{tabular}{|c|c|c|c|}
\hline & Categories & Frequency & Percentage \\
\hline $\begin{array}{c}\text { Occurrence of } \\
\text { death }\end{array}$ & Yes & 9 & $12.2 \%$ \\
\cline { 2 - 4 } & No & 65 & $87.8 \%$ \\
\hline
\end{tabular}

Table 6. Details of died infected neonates in NICU $(\mathrm{n}=9)$

\begin{tabular}{|c|c|c|c|}
\hline & Categories & Frequency & Percentage \\
\hline \multirow{2}{*}{ Sex } & Male & 2 & $22.2 \%$ \\
\hline & Female & 7 & $77.8 \%$ \\
\hline \multirow[t]{2}{*}{$\begin{array}{l}\text { Type of } \\
\text { micro } \\
\text { organism }\end{array}$} & $\begin{array}{c}\text { Enterobacter } \\
\text { Pseudomonas } \\
\text { aeurginosa } \\
\text { Candida. albicans } \\
\text { MRSA } \\
\text { MSSA } \\
\text { E. coli } \\
\text { N. mengitidis }\end{array}$ & $\begin{array}{l}1 \\
2 \\
1 \\
1 \\
1 \\
2 \\
2\end{array}$ & $\begin{array}{l}11.1 \% \\
22.2 \% \\
11.1 \% \\
11.1 \% \\
11.1 \% \\
22.2 \% \\
22.2 \%\end{array}$ \\
\hline & Maximum & Minimum & Mean (SD) \\
\hline $\begin{array}{l}\text { Gestational } \\
\text { age (weeks) }\end{array}$ & 35 & 30 & $32.4(0.4)$ \\
\hline $\begin{array}{l}\text { Birth weight } \\
\quad \text { (gm) }\end{array}$ & 2890 & 1894 & $\begin{array}{c}2491 \\
(380.2)\end{array}$ \\
\hline
\end{tabular}

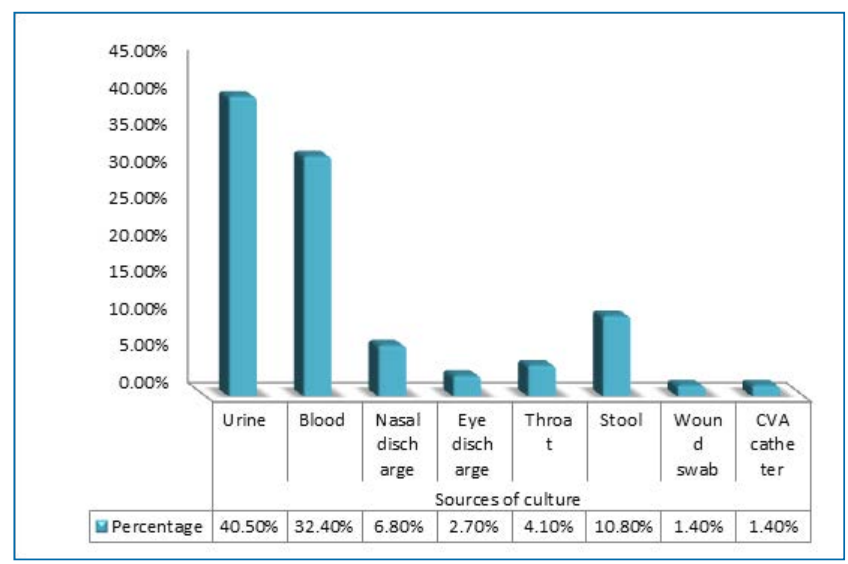

Figure 1. Sources of culture.

pattern of microbial infections during the first 72 hours of neonate life in Neonatal Intensive Care Unit.

According to the results, blood culture positivity rate in NICU cases is $32.4 \%$ which is lower than was found by I Roy et al., and Kairavi. J. Desai, et al., ${ }^{32,33}$. To manage neonatal infection properly, it is urgent to study the bacteriological profile with their antibiotic sensitivity.

The infections in NICU in the current study were more prevalent in males than in females (54\% vs. $46 \%$ ). Similarly previous studies hypothesized that septicemia

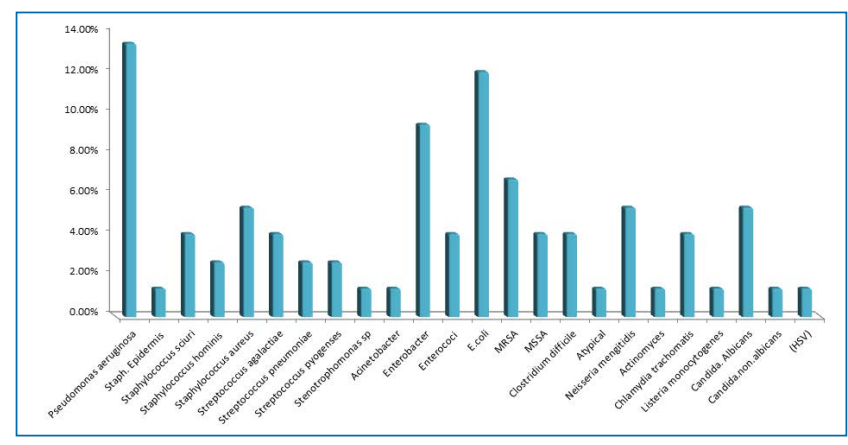

Figure 2. Distribution of microorganism isolates.

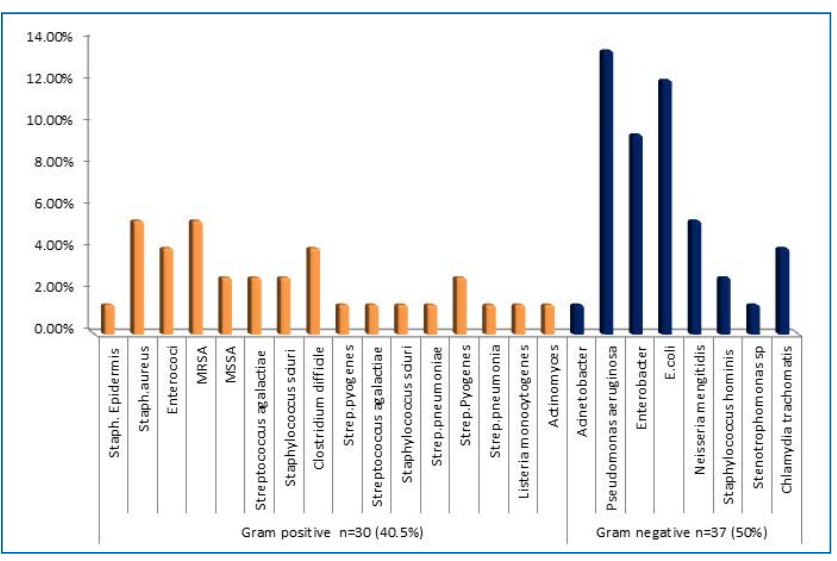

Figure 3. Distribution of isolated bacteria according to gram stain affinity.

was more in males than female neonates from 59\%-82\% because of factors which regulate gamma globulin on $\mathrm{X}$ chromosome $e^{34}$.

The most common microorganism isolated from neonates in NICU was Pseudomonas aeruginosa (13.5\%) followed by E. coli and Enterobacter (12.1\%) and (9.5\%) respectively. Other microorganisms isolated were Methecillin Resistant Staphylococcus aureus (MRSA) (6.8\%), Staph. aureus (5.4\%) and Neisseria mengitidis (5.4\%).

In previous study by Jain et al showed that Klebsiella spp. and S. aureus are most common cause of early onset septicemiain $\mathrm{NICU}^{35}$. In the present study, gram negative bacteria (50\%) were the principle pathogen causing infection in the neonates especially Pseudomonas aeruginosa (13.5\%) and E. coli (12.1\%). A study by Roy I, Jain A et al., ${ }^{32,36}$ showed similar results. Previous studies showed similar results indicated that gramnegative rods are the predominant microorganisms in NICU in Pakistan ${ }^{37,38}$. This is in contrast to other studies showed that gram-positive cocci including Staphylococcus aureus, Coagulase-negative staphylococci and group B streptococci are the predominant agents ${ }^{39,40}$. 
The isolated bacteria included 5.4\% Staohylococcus aureus which is lower than report of Narang A et al., who reported $14.3 \%$ isolates of Staphylococcus aureus ${ }^{36}$. A total of $40.5 \%$ gram positive organisms have been observed in the present study, which is higher than the results of I Roy et al., who showed $28.57 \%$ gram positive organisms ${ }^{32}$. Amongst the gram positive organisms, Staphylococcus aureus was the predominant pathogen (5.4\%). Vancomycin sensitivity was the higher among Gram negative bacterial isolates in the study (18.9\%).

The major pathogenic species of Candida differ in their frequency, virulence and clinical associations. Recent surveys continue to support the long-established pattern of C. albicans as the most frequent cause of all forms of Candidiasis. Candida parapsilosis is increasingly being recognized as an important cause of invasive candidiasis in this population ${ }^{41,42}$. Candida species have become important nosocomial pathogens in NICUs because the mechanisms of antifungal host defense that are poorly developed in neonates ${ }^{43,44}$ although $C$. albicans has been historically the most prominent species causing invasive fungal infections in premature infants, colonization and infection with non C. albicans spp. has also increased dramatically ${ }^{45}$. In the present study, other than bacterial isolates, Candida species also isolated from neonates in NICU especially Candida albicans (5.4\%) and non Candida albicans (1.4\%). Candida albicans was susceptible to azoles, but some non Candida albicans spp. exhibited decreased susceptibility to these drugs.

Recent studies revealed high incidence of both $C$. albicans and non-C. albicans candida strains causing Vulvovaginitis among pregnant women in Beirut, Lebanon.

\section{Conclusion and Recommendations}

Gram negative bacteria specifically Pseudomonas aeruginosa and E. coli are the most common causes of infection of neonates in NICU. Pathogens causing neonatal infections exhibit varying antibiotic sensitivity pattern. However, the most sensitivity recorded was for vancomycin. It is therefore essential to monitor the epidemiology of neonatal infections and continuous surveillance for antibiotic susceptibility is needed to ensure proper empirical therapy. Additionally, the emerging multi drug resistant microorganism such as Acinetobacter in NICUs could be a health risk in future.

The most commonly isolated bacteria in the present study can survive in the hospital environment therefore, strict infection control in neonatal units, rational use of antimicrobials, and protocols implementation are mandatory in the prevention of newborns infection.

\section{References}

1. Vergnano S, Menson E, Kennea N, Embleton N, Russell $A B$, Watts $T$, et al. Neonatal infections in England: The Neon IN surveillance network. Archives of Disease in Childhood-fetal and Neonatal Edition. 2011; 96(1):F9-F14. PMid:20876594. https://doi.org/10.1136/adc.2009.178798

2. Gosalia E, Mistry M, Goswami Y, Gosalia V, Vasa P. A bacteriological profile of neonatal septicemia (Study in Tertiary Care Hospital, Rajkot). International Journal of Contemporary Pediatrics. 2013; 4(2):44-7.

3. Meem M, Modak JK, Mortuza R, Morshed M, Islam MS, Saha SK. Biomarkers for diagnosis of neonatal infections: A systematic analysis of their potential as a point-of-care diagnostics. Journal of Global Health. 2011; 1(2):201.

4. Shrestha S, Shrestha N, Singh SD, Shrestha R, Kayestha S, Shrestha $\mathrm{M}$, et al. Bacterial isolates and its antibiotic susceptibility pattern in NICU. Kathmandu University Medical Journal. 2014; 11(1):66-70. PMid: 23774417. https://doi. org/10.3126/kumj.v11i1.11030

5. Bas AY, Demirel N, Zenciroglu A, Gol N, Tanir G. Nosocomial blood stream infections in a neonatal intensive care unit in Ankara, Turkey. Turk J Pediatr. 2010; 52(5):464-70.

6. Sharma CM, Agrawal RP, Sharan H, Kumar B, Sharma D, Bhatia SS. Neonatal Sepsis: Bacteria and their susceptibility pattern towards antibiotics in Neonatal Intensive Care Unit. Journal of Clinical and Diagnostic Research: JCDR. 2013; 7(11):2511. PMid: 24392386 PMCid: PMC3879858. https://doi.org/10.7860/JCDR/2013/6796.3594

7. Monsef A, Eghbalian F. Antibiotic sensitivity pattern of common bacterial pathogens in NICU and neonatal ward in Hamedan province of Iran. Health. 2010; 2(06):625. https://doi.org/10.4236/health.2010.26094

8. Mohammadi P, Kalantar E, Bahmani N, Fatemi A, Naseri $\mathrm{N}$, Ghotbi N, et al. Neonatal bacteriemia isolates and their antibiotic resistance pattern in Neonatal Insensitive Care Unit (NICU) at Beasat Hospital, Sanandaj, Iran. Acta MedicaIranica. 2014; 52(5):337-40.

9. Boskabadi H, Maamouri G, Afshari JT, Mafinejad S, Hosseini G, Mostafavi Toroghi $\mathrm{H}$, et al. Evaluation of serum interleukins-6, 8 and 10 levels as diagnostic markers 
of neonatal infection and possibility of mortality. Iranian Journal of Basic Medical Sciences 2013; 16(12):1232.

10. Yalaz M, Çetin H, Akisu M, Aydemir S. Neonatal nosocomial sepsis in a level-III NICU: Evaluation of the causative agents and antimicrobial susceptibilities. The Turkish Journal of Pediatrics. 2006; 48(1):13.

11. Darvishpour A, Hashemian H, Faal E, Fasihi M. Survey of nosocomial infection and accompanied factors in Neonatal Intensive Care Unit. Journal of Guilan University of Medical Sciences. 2010; 19(73):37-45.

12. 12. Apostolopoulou E. Nosocomial bloodstream infections in neonatal intensive care unit: Excess of length of stay, extra costs of antibiotics. ICUs Nurs Web J. 2004; 19:1-7.

13. Larypoor M, Frsad S. Evaluation of nosocomial infections in one of hospitals of Qom. 2008. Iranian Journal of Medical Microbiology. 2011; 5(3):7-17.

14. Burke JP. Infection control - a problem for patient safety. New England Journal of Medicine 2003; 348(7):651-6. PMid: 12584377. https://doi.org/10.1056/NEJMhpr020557

15. Kliegman R, Behrman RE, Nelson WE. Nelson textbook of pediatrics. Elsevier; 2016.

16. Wilson CB, Nizet V, Maldonado Y, Klein JO, Remington JS. Remington and Klein's infectious diseases of the fetus and newborn infant: Elsevier Health Sciences; 2015.

17. Kawagoe JY, Segre CA, Pereira CR, Cardoso MFS, Silva CV, Fukushima JT. Risk factors for nosocomial infections in critically ill newborns: A 5-year prospective cohort study. American Journal of Infection Control. 2001; 29(2):109-14. PMid: 11287879. https://doi.org/10.1067/mic.2001.114162

18. Eltaib L, Alanazi SA, Ali SE. Practices and attitudes concerning expiration date, unused and expired medication disposal. Int J Med Sci Public Health. 2020; 9(7):431-8. https://doi.org/10.5455/ijmsph.2020.06099202010082020

19. Report of the National Neonatal Perinatal Database (National Neonatology Forum). 2002-03.

20. Boskabad H, Moudi A, Parvini Z, Barati T. Evaluation of the cause and related factors of neonatal mortality in Qaem hospital 1388-89. The Iranian Journal of Obstetrics, Gynecology and Infertility. 2012; 14(7):21-6.

21. Taeusch HW, Ballard RA, Gleason CA, Avery ME. Avery's diseases of the newborn: Elsevier Health Sciences; 2005. Lina Eltaib, Bashaer W. Alenzi, Parents Knowledge, Attitude and Practices regarding children vaccination in Northern Border Area (Saudi Arabia): Cross Sectional Study, Indo Am. J.P. Sci. 2020; 07(09).

22. Brightman VJ, Scott TF, Westphal M, Boggs TR. An outbreak of coxsackie B-5 virus infection in a newborn nursery. J Pediatr. 1966; 69:179-92. https://doi.org/10.1016/S00223476(66)80318-9

23. Boskabadi H, Maamouri G, Mafinejad S. Neonatal complications related with prolonged rupture of membranes.
Macedonian Journal of Medical Sciences. 2011; 4(1):93-8. https://doi.org/10.3889/MJMS.1857-5773.2011.0177

24. Romero R, Chaiworapongsa T, Espinoza J. Micronutrients and intrauterine infection, preterm birth and the fetal inflammatory response syndrome. The Journal of Nutrition. 2003; 133(5):1668S-73S. PMid: 12730483. https://doi. org/10.1093/jn/133.5.1668S

25. Sundaram V, Kumar P, Dutta S, et al. Blood culture confirmed bacterial sepsis in neonates in a North Indian tertiary care center: Changes over the last decade. Jpn J Infect Dis. 2009: 62;46-50.

26. Patel, Sameer J, et al. Gram-negative Bacilli in infants hospitalized in the Neonatal Intensive Care Unit. Journal of the Pediatric Infectious Diseases Society. 2017; 6(3):227-30. PMid: 27302327 PMCid: PMC5907873. doi:10.1093/jpids/ piw032 https://doi.org/10.1093/jpids/piw032

27. Harris J, Goldmann D. Infections acquired in the nursery: Epidemiology and control. Remington JS, Klein JO, eds. Infectious diseases of the fetus, newborn and infants, 5th ed. Philadelphia: WB Saunders; 2001. p. 1371-418.

28. Klein JO. Bacterial sepsis and meningitis. Remington JS, Klein JO, eds. Infectious diseases of the fetus, newborn and infants, 5th ed. Philadelphia: WB Saunders; 2001. p. 943-84.

29. Eltaib L, Mujtaba MA, Amir D, Rikabi H. Evaluation of community pharmacist dispensing and counseling practice. International Journal of Biology, Pharmacy and Allied Sciences. 2019. https://doi.org/10.31032/ IJBPAS/2019/8.6.4745

30. Korpela JK, Campbell J, Singh N. Health care associated infections. Mhairi MG, Mullett MD, Seshia MM, ed. Avery's Neonatology: Pathophysiology and Management of the Newborn. Philadelphia: Lippincott Williams Wilkins; 2005. p. 1356-83.

31. Roy A, Jain M, Kumar M, Agarwal SK. Bacteriology of neonatal septicemia in a tertiary care hospital of northern India. Indian J Med Microbiol. 2002; 20:156-9.

32. Desai KJ, Malek S. Neonatal Septicemia: Bacterial isolates and their antibiotics susceptibility patterns. National Journal of Integrated Research in Medicine. 2010; 1:12-5.

33. Schreiber JR, Berger M. Intravenous immune globulin therapy for sepsis in premature neonates. J Pediatr. 1992; 121:401-4. https://doi.org/10.1016/S00223476(05)81794-9

34. Jain A, Roy I, Gupta M, Kumar M, Agarwal SK. Prevalence of extended-spectrum $\beta$-lactamase-producing Gramnegative bacteria in septicaemic neonates in a tertiary care hospital. J Medical Microbiol. 2003; 52:421-5. PMid: 12721319. https://doi.org/10.1099/jmm.0.04966-0

35. Narang A, Rao R, Bhakoo ON. Neonatal necrotizing enterocolitis: A clinical study. Indian Pediatr. 1993; 30:1417-22. 
36. Bhutta ZA, Naqvi SH, Muzaffar T. Neonatal sepsis in Pakistan. Acta Paediatr Scand. 1991; 80:596-601. PMid: 1867074. https://doi.org/10.1111/j.1651-2227.1991. tb11916.x

37. Khan IA, Akram DS. Neonatal sepsis - etiological study. J Pak Med Assoc. 1987; 37:327-30.

38. Ako-Nai AK, Adejuyigbe EA, Ajayi FM, Onipede AO. The bacteriology of neonatal septicaemia in lle-Ife, Nigeria. J Trop Pediatr. 1999; 45:146-51. PMid: 10401192. https:// doi.org/10.1093/tropej/45.3.146

39. Kaushik SL, Parmar VR, Grover N, Grover PS, Kaushik R. Neonatal sepsis in hospital born babies. J Commun Dis. 1998; 30:147-52.

40. Stoll BJ, Hansen N, Fanaroff AA, Wright LL, Carlo WA, Ehrenkranz RA, et al. Late-onset sepsis in very low birth weight neonates: The experience of the NICHD Neonatal Research Network. Pediatrics. 2002; 110(2Pt1):285-91. PMid: 12165580. https://doi.org/10.1542/peds.110.2.285

41. Fridkin SK, Kaufman D, Edwards JR, Shetty S, Horan T. Changing incidence of Candida bloodstream infections among NICU patients in the United States: 1995-2004. Pediatrics. 2006; 117(5):1680-7. PMid: 16651324. https:// doi.org/10.1542/peds.2005-1996
42. Manzoni P, Farina D, Leonessa M, d'Oulx EA, Galletto P, Mostert $\mathrm{M}$, et al. Risk factors for progression to invasive fungal infection in preterm neonates with fungal colonization. Pediatrics. 2006; 118(6):2359-64. PMid: 17142519. https://doi.org/10.1542/peds.2006-1311

43. Mahieu LM, Van Gasse N, Wildemeersch D, Jansens H, Ieven M. Number of sites of perinatal Candida colonization and neutropenia are associated with nosocomial candidemia in the neonatal intensive care unit patient. Pediatr Crit Care Med. 2010; 11(2):240-5. PMid: 19794324. https:// doi.org/10.1097/PCC.0b013e3181b808fb

44. Mendiratta DK, Rawat V, Thamke D, Chaturvedi P, Chhabra S, Narang P. Candida colonization in preterm babies admitted to neonatal intensive care unit in the rural setting. Indian J Med Microbiol. 2006; 24(4):263-7. PMid: 17185844. https://doi.org/10.4103/0255-0857.29384

45. Farmaki E, Evdoridou J, Pouliou T, Bibashi E, Panagopoulou P, Filioti J, et al. Fungal colonization in the neonatal intensive care unit: Risk factors, drug susceptibility and association with invasive fungal infections. Am J Perinatol. 2007; 24(2):127-35. PMid: 17304423. https://doi. org/10.1055/s-2007-970078 